\title{
The Effect Of Skills Education On The Self-Study Capability Of New Students Universitas Terbuka
}

\section{Gede Suwardika ${ }^{1 *}$, Hendrin Hariati Sawitri²}

${ }^{1}$ Prodi Statistika ? Universitas Terbuka

${ }^{2}$ Prodi Ekonomi ? Universitas

\section{A R T I C L E I N F O}

Article history:

Received 01 December 2018

Received in revised form

31 December 2018

Accepted 15 January 2019

Available online 25

February 2019

\section{Keywords:}

Education, Self-Learning

Skills, self-study success

\section{A B S T R A C T}

The purpose of this study is to observe the Impact of the Independent Learning Skills Education on the Self-Learning Readiness of New Students by 2018. We use the Analysis Path to observe the Student' s Self-Learning Readiness consisting of time management skills, effective module reading, recording of reading skills, tutorial, and skill of accessing service on line. The Results suggest that Skills Education is an important factor affecting their study in the future 


\section{Introduction}

The application of self-learning concept to Open University (Universitas Terbuka/UT) students is important especially for new students, considering that UT students do not interact much with the lecturers and tutors.

It has been a routine problem that UT students after the first registration, most of them have not understood what to do in preparing for their independent learning. Similarly, mentioned problem as well is experienced by new students in UT Denpasar region.

When new students make their first registration they are as well given study orientation. The orientation of this study involves introducing the Distance Education system to students, which its goal is to introduce what and how to learn independently. However, the 1-day orientation is less able to assist students in their implementation as students who must learn independently.

According to Slameto (Slameto 2010 in Vovi Sinta B, 2017), learning is a an effort undertaken by a person to gain a whole new behavioral change, as a result of his own experience in interaction with his environment. With Slameto's opinion, it is concluded that learning is an absolute necessity for students

to succeed.

Independent Learning according to Paulina Pannen (Pannen P 2001 in Trisiana Anita, 2014), is defined as an autonomous individual student effort to achieve an academic competence. Self study provides students the opportunity to. 1) Determining the learning themselves, 2) planning the learning process, 3) using the learning resources they choose, 4) making academic decisions, 5) doing the activities they choose to achieve their learning objectives. With Slameto and Pannen's opinion it is understandable that self-study and learning are the most important and relevant things to apply to distance education students.

Sawitri Hendrin in her research mentioned that although the students have been given information about the concept of independent learning at the time of New Students Study Orientaion (NSSO) but in fact, while facing the test they are considered not ready (Sawitri H., 2017). Most UT students still need guidance in their studies, as research conducted by Darmayanti suggests that distance education students need institutional help to improve their self-learning skills. The assistance is in the form of advisory assistance, psychological guidance to first year students, because in the first year distance education is the year of adjustment to face different environment that is different from face-to-face system (Darmayanti, 2005).

Self-learning resources are not only formed as printed material that can be taken anywhere but has developed and formed as a cyber-based teaching materials (cyberspace). Darmayanti in her writing said the new Paradigm that appears related to the learning process that no longer describes face-to-face meetings in the classroom has now been widely accepted and has so influenced and impacted human life. The presence of Internet technology makes it easier for people to interact without being bound by time and space again. The term cyberspace, often used in science fiction and depicting cyberspace, is now frequently used (Darmayanti 2007)

With the change of paradigm, the Institution needs to provide stock for students to be able to take advantage of cyber technology in the way of learning.

According to Sumarmo (Sumarmo 2004 in Nurhayati Elis 2017) that the main characteristics of learning independence are: 1) analyzing the learning needs of mathematics, formulating goals, and designing learning programs; 2) selecting and implementing learning strategies; 3) monitoring and studying learning are: 1) analyzing the learning needs of mathematics, formulating goals, and designing learning programs; 2) selecting and implementing learning strategies; 3) monitoring and self-evaluation, whether the strategy has been implemented correctly, examining the results (processes and products), and reflecting on getting feedback (Sumarmo, 2004: 5).

Guglielmino and Guglielmino (Guglielmino \& Guglielmino 1991 in Samsul Islam 2010) in their research mentioned that the level of independence demanded in learning situations is different from each other. The differences vary from teacher-directed learning setting to learning situations that require student-directed learning setting (Islam S, 2010).

Guglielmino's independent learning process begins with identifying learning needs, continuing to determine learning objectives, then preparing a learning plan, continuing to find the necessary resources, then implementing a learning plan up to evaluate learning outcomes and learning processes (Geglielmino \& Guglielmino, 1991 in Islam Samsul 2010)

The distance education institution in this case UT Denpasar participates in assisting the development of students' self-learning ability through Student Skills Education (SSE) activity. The SSE activity is a form of Institutional Intervention to UT students in terms of providing information on Self 
Learning Concepts, Time Manage Skills, Effective Reading Skills Module, Read Recording Skills, Skills on Tutorials and Skills of Online Services Access.

Welcoming the policy of Vice Rector for Academic about the Training of Student Skills Education Skill (SSE) conducted in 2018.1, hopefully this new student self-study skills training can provide strengthening and preparation of learning for new students in the learning process.

This research was conducted to find out the extent to which SSE conducted by UT Denpasar provide assistance to students so that students are able to learn independently.

\section{Methods}

This study is a qualitative research that aims to analyze the opinions of respondents, in this case is new students, to know the understanding and self-learning skills of new students. To find out how big the relation between each independent variable to dependent variable use Likert Scale aid so get quantitative number which then analyzed by using program Eviews 5 .

The study population is the new students of UT Denpasar during registration 2018.1. New students are assumed to be unaware of self-learning readiness information in UT. Data samples are students in Badung, Tabanan, Jembrana and Denpasar districts.

As a sample of new students is a freshman 2018.1 February, a total of 175 students. Data for measuring each variable were collected by using questionnaire instrument. This questionnaire contains items of questions that illustrate the perceptions of the benefits and importance of Self-Study Skills Education (SSE) in the student learning process.

The method used is survey method. To find out overall how big the relationship between Giving SSE with Student Self Learning Ability, path analysis is used.

Path Analysis is an extension of multiple linear regression analysis used to estimate the causal relationship between variables (causal model) based on theory. This analysis is also useful to know the relationship between independent variables with dependent and indirect relationship through intervening.

The steps in path analysis are:

Designing models based on theoretical concepts are as follows:

B3

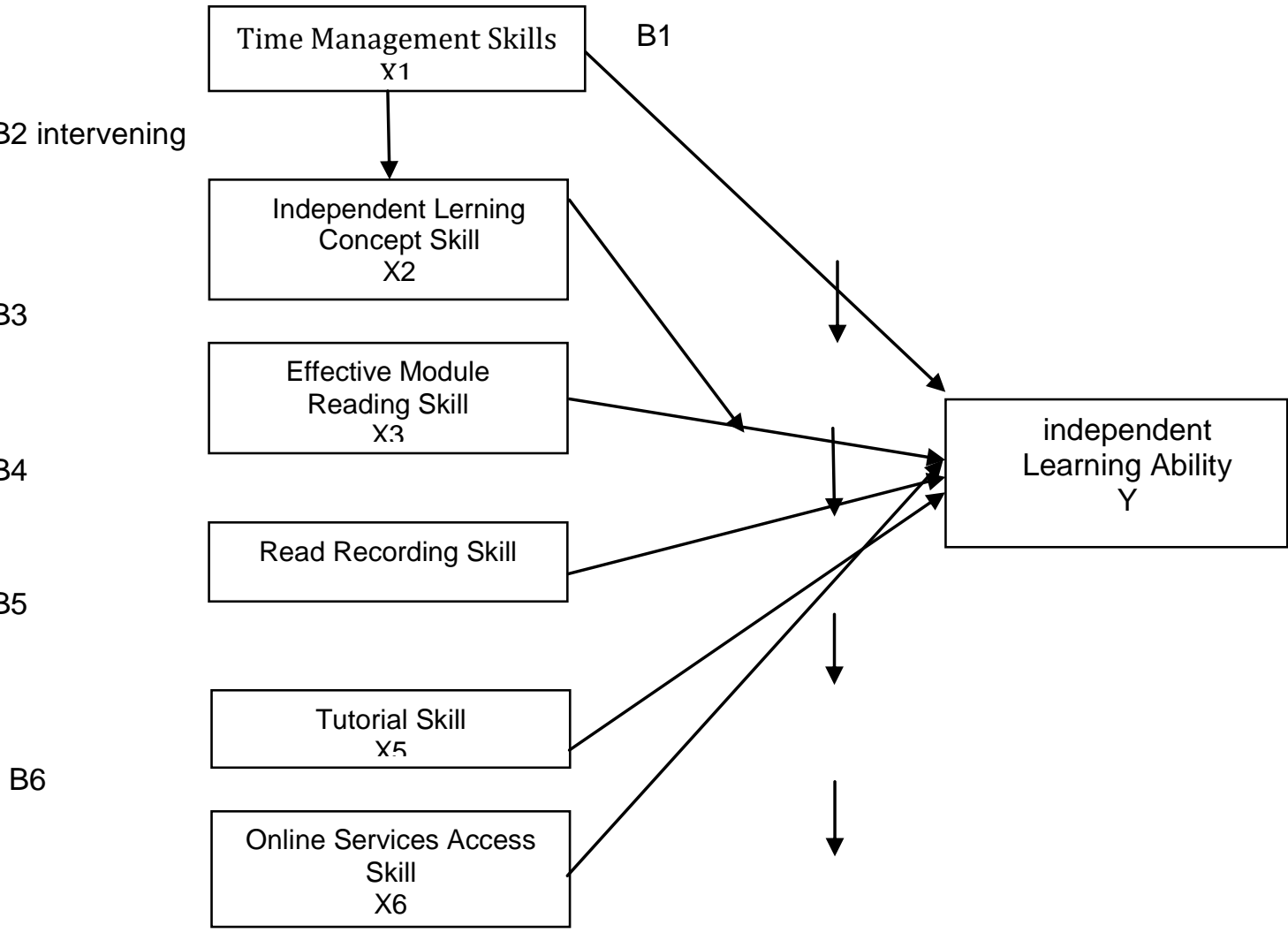

B2 intervening

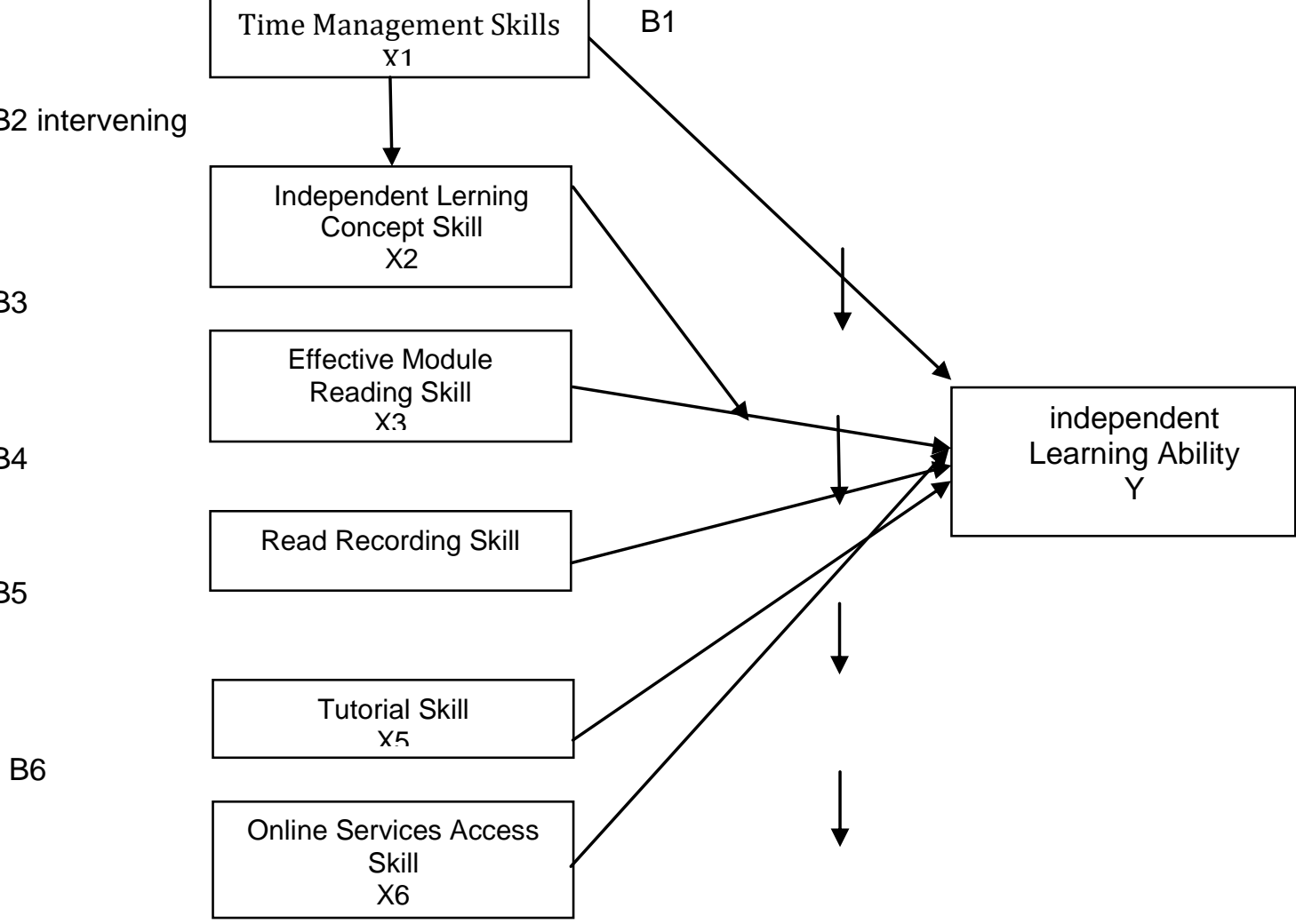

B1

Picture 1 Path Analysis Model 
a. Time management skill as variable affects directly to the students? independent learning ability

b. Independent learning concept as variable moderates the effect of students? ability in reading modules effectively to the students? learning ability

c. Effective module reading skill as variable moderated by Independent Learning Concept, affects directly to Students回s Learning Ability

d. Read Recording Skill as variable affects directly to the Students? Learning Ability.

e. Tutorial Skill as variable affects directly to Independent Learning Ability

f. Online services access skill as variable affects directly to Independent Learning Ability

g. Simultaneously, variables mentioned, time management skill, independent learning concept, effective module reading skill, read recording skill, tutorial skill and online services access skill affect independent learning ability

\section{Determining the equation of the structural model:}

Structural Equation

$$
Y=c+a_{1} X_{1}+a_{2} X_{2}+a_{2} X_{3}+a_{4} X_{4}+a_{5} X 5+a_{6} X_{6}+e_{7}
$$

Information

$\mathrm{Y}=$ Students[ Independent Learning Ability

$\mathrm{b}=$ Path Coeficient

$\mathrm{X}_{1}=$ Time Management Skill

$\mathrm{X}_{2}=$ Independent Learning Concept

$\mathrm{X}_{3}=$ Effective Module Reading Skill

$\mathrm{X}_{4}=$ Read Recording Skill

$\mathrm{X}_{5}=$ Tutorial Skill

$\mathrm{X}_{6}=$ Online Services Access Skill

$\mathrm{e}=$ Error

The equation states that there are six structural relations where the first relationship is causal relationship from $X_{1}$ to $Y$. The second relationship, which states causal relationships from $X_{2}$ and $X_{3}$ to $Y$. The third relationship states the causal relation between $X_{1}, X_{2}$ and $X_{3}$ to $Y$. The fourth relationship states the causal relationship between $\mathrm{X}_{1}, \mathrm{X}_{2}, \mathrm{X}_{3}$ and $\mathrm{X}_{4}$ to $\mathrm{Y}$. The fifth relation states the causal relationship between $\mathrm{X}_{5}$ and $\mathrm{Y}$. The sixth relationship states the causal relationship between $\mathrm{X}_{6}$ and $\mathrm{Y}$. Simultaneously expressing causal relationship between $\mathrm{X}_{1}, \mathrm{X}_{2}, \mathrm{X}_{3}, \mathrm{X}_{4}, \mathrm{X}_{5}$, and $\mathrm{X}_{6}$ to $\mathrm{Y}$.

Table 1. Direct and Indirect Effect and Total Effect

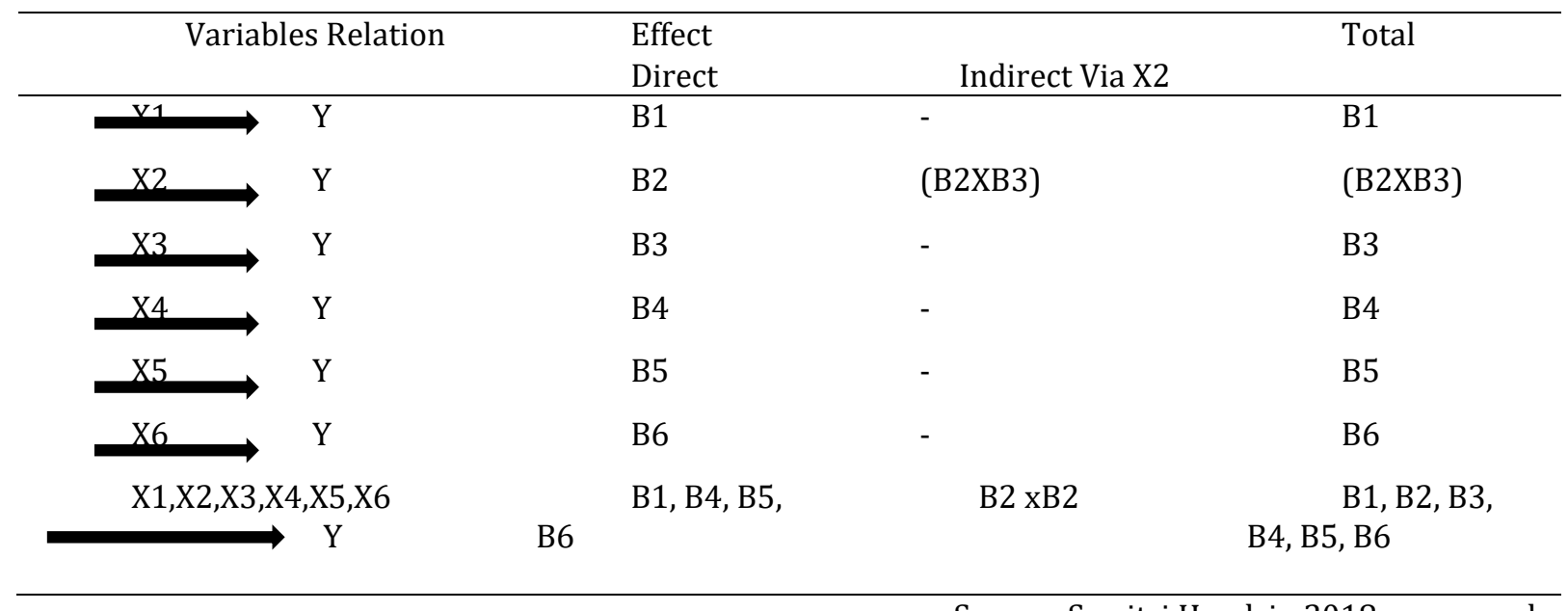


Referring to the research of Samsul Islam (Islam S, 2010), that the criteria of student self-skill level is measured by the average number of scores on each variable on Likert Scale as criteria below:

Table 2. SDLRS Score Interpretation

\begin{tabular}{ll}
\hline Score & Independent Learning Skiill Level \\
\hline $252-290$ & High \\
$227-251$ & Above average \\
$202-226$ & Average \\
$177-201$ & Below average \\
$58-176$ & Low \\
\hline & Source : ? The learning preferences assesment? oleh L.M. Guglielmino \& P.J. Guglielmino
\end{tabular}

(1991, p.8)

Based on the table as a reference then the level of self-learning ability with modifications can be described as the following table, with Likert scale with a score of 1,2,3,4,5 where:

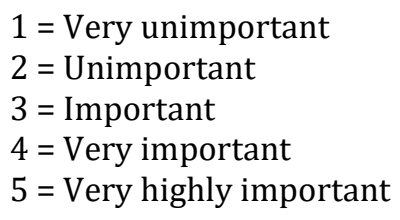

Table 3. Open University (UT) New Students? Independent Learning Ability

\begin{tabular}{cl}
\hline Score (29 item) & Average Score of UT New Students? Independent Learning Ability Level \\
\hline $127-145$ & High \\
$116-126$ & Above average \\
$87-115$ & Average \\
$58-86$ & Below average \\
$29-57$ & Low \\
\hline
\end{tabular}

Source : citated from Samsul Islam, 2010, modified.

\section{Result And Discussion}

Structural Equation

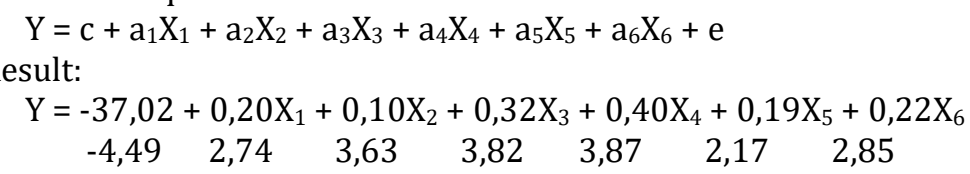

Table 4. SIGNIFICANCE (Dependent Variable : Y)

\begin{tabular}{|c|c|c|c|c|}
\hline Variable & Coeficient & $t$ count & t table $(\alpha, n-k)$ & Conclusion \\
\hline $\mathrm{C}$ & $-37,02$ & $-4,49$ & $1,96(0.05,169)$ & $-(4,49)>1,96$ Significant \\
\hline $\mathrm{X} 1$ & 0,20 & 2,74 & $1,96(0,05,169)$ & $2,74>1,96$ Significant \\
\hline $\mathrm{X} 2$ & 0,10 & 3,63 & $1,96(0,05,169)$ & $3,63>1,96$ Significant \\
\hline X3 & 0,32 & 3,82 & $1,96(0,05,169)$ & $3,82>1,96$ Significant \\
\hline $\mathrm{X} 4$ & 0,40 & 3,87 & $1,96(0,05,169)$ & $3,87>1,96$ Significant \\
\hline $\mathrm{X} 5$ & 0,19 & 2,17 & $1,96(0,05,169)$ & $2,17>1,96$ Significant \\
\hline X6 & 0,22 & $\begin{array}{l}2,85 \\
\text { count }\end{array}$ & $\begin{array}{l}1,96(0,05,169) \\
\text { table }\end{array}$ & $2,85>1,96$ Significant \\
\hline R-Squared & 0,62 & & & \\
\hline $\mathrm{D}-\mathrm{W}$ & & 1,43 & $\begin{array}{l}\mathrm{dl}=1,68(\mathrm{k}=6,169) \\
\mathrm{du}=1,80(\mathrm{k}=6,169)\end{array}$ & $\begin{array}{l}4-\mathrm{d}>\mathrm{du}, 2,57>1,81 \\
\text { No negative autocorrelation }\end{array}$ \\
\hline F Stat & & 45,5 & $2,18(0.05,6,169)$ & $\begin{array}{l}45,5>2,18 \\
\text { regression equation Y over X: significant }\end{array}$ \\
\hline
\end{tabular}


From the results, it can be seen that the variables of time management (X1), independent learning concept (X2), variables of effective module reading skill (X3), read recording skill (X4), and skill of accessing online service (X6) have a positive effect on the variable of independent learning ability (Y) significantly.

While the coefficient of $\mathrm{X} 1$ is 0.20 , the coefficient of $\mathrm{X} 2$ is 0.10 , the coefficient of $\mathrm{X} 3$ is 0.32 , the coefficient of X4 is 0.40 , the coefficient of X5 is 0.19 and the coefficient of X6 is 0.22 , it means that if X1, X2, $\mathrm{X} 3, \mathrm{X} 4, \mathrm{X} 5$ and $\mathrm{X} 6$ are raised each 1 unit will raise $\mathrm{Y}$ by $0.20,0.10,0.32,0.40,0.19$ and 0.22 units. The seriousness of the students in the skills of managing time, understanding the concept of self-learning, the ability to read modules effectively, recording skills of reading, skills to carry out tutorials and skills to access online services will affect the ability of independent learning. Judging from the tendency to influence the dependent variable, the biggest coefficient is the coefficient $\mathrm{X} 4$ that is the read recording skills of reading result $(0,40)$, then coefficient X3 is the skill of reading module effectively $(0,32)$ and coefficient X6 $(0,22)$ that is skill of accessing service online. These skills are indeed required by every student in independent learning. Therefore, it is expected that with the training of independent learning skills education, students will succeed in learning with Distance Education system.

Viewed from the $F$ test, $F$ value count $=45.5$ and $F$ value table of $2.18(\mathrm{df} / \mathrm{df} 2,6 / 169, \alpha=0,05)$ turns $\mathrm{F}$ count is greater than $\mathrm{F}$ table so it can be concluded that simultaneously the independent variable may explain the dependent variable or the independent variable has a relationship relevant to the dependent variable.

Viewed from the Durbin Watson statistic, the DW value is calculated at 1.43, from the calculation that $4-\mathrm{d}(4-1.43=2.57)$ is greater than $\mathrm{dU} 1.81(\mathrm{k}=6, \alpha=0.05)$ which meaning there is no negative autocorrelation between the variables in the study in the level of $95 \%$.

The value of R-Square 0.62 , which means $62 \%$ of the dependent variable can be explained by independent variables, so there are still variables beyond the 6 independent variables that can affect students' independent learning ability.

Average Score of Each Variable

From the results of coding data on each variable obtained the average Score figures as the following table

Tabel 5. Average Score of Each Variable

\begin{tabular}{lll}
\hline Variable & Number of Item & Average score \\
\hline X1 & 3 & 13 \\
X2 & 1 & 5 \\
X3 & 9 & 40 \\
X4 & 2 & 9 \\
X5 & 8 & 35 \\
X6 & 4 & 17 \\
Y & 2 & 9 \\
Total & 29 & 126 \\
\hline
\end{tabular}

Source : Sawitri Hendrin 2018, processed

The New Student Independent Learning Ability level can be seen from the criteria of the average score on each variable. While from Table 5, the average score of 126 is obtained, which means that this figure is at the level of independent learning ability of new students UPBJJ-UT Denpasar 2018.1 above the average.

The results of this study indicate that the provision of skills training for self-study to new students during registration 2018.1 at UPBJJ-UT Denpasar conducted by Institution in this case is UPBJJ-UT Denpasar showed significant level of ability. Time-managing skills, self-learning concepts, effective module reading skills, recording skills of reading skills, tutorial skills and online service access skills positively influence significant self-learning abilities. The self-learning ability shows an above-average ability that is considered by students to be very important. However, the success of independent learning is determined by many factors, there are other factors beyond this study that can determine the success of students such as self-motivation, environment and other events that can affect student self-study 


\section{Conclusion}

According to the result of this research, it could be concluded that: 1 . The skills of managing new student registration during 2018.1 can affect students' self-study ability by $0.20,2$. The concept of selflearning can affect the ability of self-study by $0.10,3$. Module reading skills can effectively affect the selfstudy ability of $0.32,4$. Recording skills of reading can affect the ability of independent learning by $0.40,5$. Skill of executing tutorial can affect self study ability equal to $0,19,6$. The skills of accessing online services can affect the self-learning ability of $0.22,7$. The level of self-learning ability of new students UPBJJ-UT Denpasar 2018.1 above the average

Based on the result of research, it is suggested some things as follows: 1 . The concept of independent learning should continue to be given to students so they can understand and can implement self-learning well, although on average they already understand about the concept of self-learning 2 . UT as the institution of Distance Eduaction organizer must provide learning assistance services such as Faceto-Face Tutorial and Tutorial On line (TUTON) required by students at UT Denpasar level, such as Faceto-Face schedule information, tutorial course, TUTON activation and TUTON schedule 3. UT provides online service facilities both online services for learning resource materials, study assistance, online exams as well as online services for student administration such as online registration, online exam result information and other online administration services, 4. UT continuously organizes the ability to read modules effectively, recording skills which are very useful for the development of self-study of students, and 5. UT conducts academic guidance and skills to students, especially students who conduct practicum so they can carry out the practicum well.

\section{Reference}

Darmayanti T., (2005). Efektivitas Intervensi Keterampilan Self-Regulated learning dan Keteladanan Dalam Meningkatkan Kemampuan Belajar Mandiri dan Prestasi Belajar Mahasiswa Pendidikan Jarak Jauh. Unpublished dissertation, Jakarta : Universitas Indonesia.

Darmayanti T dkk ., (2007). E-Learning Pada Pendidikan Jarak Jauh: Konsep yang Mengubah Metode Pembelajaran di Perguruan Tinggi di Indonesia, Jurnal Pendidikan Terbuka dan Jarak Jauh, volume 8, No 2, September

Darmayanti T dkk, (2011), Studi Jangka Panjang Tentang Efektivitas Intervensi Psikologis Dalam Meningkatkan Kemampuan Belajar Mandiri Dan Prestasi Belajar Mahasiswa pendidikan Jarak Jauh, Jurnal Pendidikan Jarak Jauh, Volume 12, No 1, March 2011

Guglielmino, L.M.\& Guglielmino, P.J.(1991). Expanding your readiness for self directed learning. Don Mills.Ontario: Organization Design and Development Inc.

Islam S., (2000)., Prestasi Belajar, Kesiapan belajar mandiri dan konsep diri mahasiswa pada system pendidikan terbuka dan jarak jauh: Suatu Studi korelasional di Universitas Terbuka(1997). Unpublished thesis. Jakarta : Program Pascasarjana Universitas Negeri Jakarta.,

Nurhayati Elis. (2017)., Penerapan Scaffolding Untuk Mencapai Kemandirian Belajar Siswa, Jurnal Penelitian Pendidikan dan Pengajaran Matematika, Vol 3 No 1, March 2017

Sawitri H. (2017)., Manfaat Orientasi Studi Mahasiswa Baru (OSMB) Pada Kesiapan Belajar Mandiri Mahasiswa UPBJJ-UT Denpasar, makalah pada Konferensi tahunan Asia Association of Open University (AAOU), Yogyakarta, 2017

Sinta B Vovi., (2017). Pengaruh Kesiapan Belajar Terhadap Hasil Belajar Mata Pelajaran Ekonomi Kelas X di SMA Bina Jaya Palembang, UTILITY: Jurnal Ilmiah Pendidikan Ekonomi, Vol 1, No 1, February (p. 14)

Sugiyono (2015), Statistika untuk Penelitian, Alfabeta, Bandung, 26th edition

Trisiana A., (2014). Optimalisasi Belajar Mandiri Tata Pamong (Tinjauan Kritis dan Pengembangan Terhadap Peningkatan Kualitas Sumber Daya Manusia yang Berkarakter, Jurnal Widya Wacana, Vol 9, No 2, August (p.53) 